\title{
How Predictive Is the Match Between Children's Emergent Literacy Skills With Maternal Reading Proficiency From Early Childhood Education to Literacy Skills Acquisition in Primary Five? Evidence From Ghana
}

\author{
Stephen Ntim \\ Faculty of Education, Catholic University College of Ghana, Ghana \\ E-mail: stephen.ntim@cug.edu.gh; stephenntim58@yahoo.com; stephenntim58@gmail.com
}

Received: August 19, 2020

doi: 10.5296/ire.v9i1.17570
Accepted: February 15, $2021 \quad$ Published: February 17, 2021

URL: https://doi.org/10.5296/ire.v9i1.17570

\begin{abstract}
This longitudinal study investigated the predictive power of the match between home literary practices, especially maternal reading proficiency and children's emergent literacy skills at preschool, and how these implicate children's literacy acquisition at primary five. Using stratified random purposive sampling of two hundred and fifty two (252) participants, comprising one hundred and twenty mothers, one hundred and twenty kindergarten children, and twelve kindergarten teachers responses measured using multiple linear regression models, the following were the major findings: a) parental education especially that of the mother was the most significant factor; b) phonological and morphological awareness during preschool at age 4 mediated causal connection to early family socioeconomic status and children's ability at age 11 on character recognition; c) children's vocabulary acquisition at age 4 mediated a correlation between early family factors such as mother's socioeconomic status and mother-child reading tuition at home and how fluent children can read at age 11. The conclusion of this study is that it difficult to significantly improve early family environmental factors of some children, nevertheless, designing classroom intervention for disadvantaged children on cognitive and linguistic skills is feasible and possible to compensate for environmental disadvantage.
\end{abstract}

Keywords: Maternal reading proficiency, Emergent literacy skills, Literacy acquisition 


\section{Introduction}

At the core of all educational experiences is the acquisition of literacy skills: reading, writing and computation. These are the building blocks for competent and educated adults in a world that is fast becoming more and more competitive. The acquisition of literacy skills more than ever is critically essential for basic survival in the contemporary world. The student with challenges in reading, writing and computing is likely to struggle in other subject domains, a situation that can affect and perpetuate a negative predisposition towards formal education generally. It is in this respect that early exposure to reading, for example from the home before the formal school years is highly commendable. It can greatly predict greater success in school (Anderson \& Cheung, 2003). Therefore, a child without this early home exposure cannot keep up with peers, since early exposure to reading fosters the development of positive attitudes to reading (Lawson, 2012). Indeed, contemporary research findings in reading, continue to suggest the convergence between enhanced reading from the home and the acquisition of emergent literacy skills in early childhood education, which some thirty years ago was believed to start at the level of formal schooling. Scientific research in children's emergent literacy skills highlight the preschool period as critical for laying the foundations for later literacy (Whitehurst \& Lonigan, 2001).

Children's development of early literacy skills is closely connected to parents, especially the mother and the entire home environment. It is in the home that language and literacy are first encountered (Hart \& Risley, 1995; Strickland, 1990). Consequently, a home environment with the requisite opportunity for parents to read to the child, enhances the development of foundational skills as well as language abilities (Bus, van Ijzendoorn, \& Pelligrini, 1995; Klesius \& Griffith, 1996; Dickison \& Tabor, 2001; Storch \&Whitehurst, 2001). Even though, Education in this $21^{\text {st }}$ century is perceived to be equitable, nevertheless, research findings continue to suggest that children exposed to pre-reading from the homes such as phonological awareness, phoneme blending, segmenting skills and knowledge of print concepts have comparative advantage over those who did not have such exposure (Roberts et al., 2005). In this sense, inasmuch as reading constitutes one of the most critical skills every child needs to acquire during the elementary grades, it is still very difficult for many children (Swank \& Catts, 1994). One of the underlying difficulties is the fact that reading is a complex cognitive behaviour. It is heavily underpinned not just by cognitive and linguistic aspects (Swank \& Catts, 1994), but also by the affective dimension especially attitude to reading, motivation, interest of the child, his/her personal interest and values, etc.- all of which are intrinsically connected to the child's self-concept (Garret, 2002). This self-concept referred to as attribution in psychological literature is not unrelated to parental influence especially the mother. Thus, the intrinsic connectivity between the emergent literacy skills with which children enter preschool and their later academic performance have consistently been striking in research studies. For example, studies indicate that there is almost $90 \%$ probability that a child who enters first grade as a poor reader, will continue to be a poor reader by the fourth grade. Similarly, a child with knowledge in emergent literacy such as letter identification at the kindergarten level is highly predicted to be an efficient reader at the tenth grade (Boyer, 1991). This indicates that the correlation between home literacy environment and preschool continue to be important variables in children's emergent literacy skills especially reading 
and writing development (Burgess, Hecht \& Lonigan, 2002; Hood, Conlon, \& Andrews, 2008; Sénéchal \& Young, 2008; Weigel, Martin, \& Bennett, 2005, Ntim, 2014; Ntim \& Okyere, 2014).

'Emergent literacy' as used in this paper refers to all the exploratory processes of reading and writing experiences that children are exposed to before learning formal reading and writing (Teale, \& Sulzby (1986). It is not so much about the learning of phonics, spelling or even demonstration of comprehension as such- all of which are conventional literacy skills. Rather, they refer to all the seminal experiences from the home that initiate exploratory literacy skills for conventional instruction. It is within this context that emergent literacy is assumed to begin at a very tender age such as infancy and toddler. It is believed that even at these ages, children engage in a variety of experiences dealing with both oral and written language. They hear parents speaking and see them writing. Embedded in such interactions, they see print and want to experiment with it. They see parents using print and want to imitate them. Thus, from the onset of such social interaction, infants who lack these home exposure (all things being equal), are likely to encounter challenges keeping up with peers whose early exposure to reading fosters the development of positive attitudes to reading (Lawson, 2012).

\subsection{Statement of Problem}

The last several years have witnessed a global shift in educational debate from educational access to enhancing the quality of learning outcomes. This notwithstanding, in many geopolitical areas, classroom interventions on reading initiatives focuses almost exclusively in the early primary grades and neglect the irreplaceable role that foundational emergent literacy plays before formal schooling. Additionally, contemporary research in literacy skills and language development continue to suggest that basis for learning, reading and writing are prior to primary school and the timing for this process to start is important to underscore and there is a crucial connection between emergent literacy skills and later reading outcomes. Becoming literate is de facto socially embedded with the kind of experiences children have with language and print from birth onwards. Given the fact that enhancing reading, writing and computation skills of young children through emergent literacy skills even before formal schooling is critical to academic success (Snow, Burn, \& Griffin 1998), there is still a substantial number of children in Ghana and many African countries who enter kindergarten with limited and deficient literacy skills. Home literacy practices are therefore critical to children's early development. When parents themselves have poor or no literacy skills, children from such background typically have difficulty catching up in school (Bowman, Donvan, \& Burns, 2001). Since home literacy practices impact heavily on children's emergent literacy skills development, it is critical that scientific research in Ghana and Africa explore these sources especially maternal reading proficiency whether or not it modulates children's emergent literacy skills and later literacy skills at primary five.

\subsection{Research Questions}

The following questions guided this study:

1) How strong is the predictive power between maternal reading proficiency and children's emergent literacy skills? 
2) In what sense does the quality of home environment and socioeconomic status predict children's emergent literacy skills?

3) Is the association between maternal reading proficiency and children's emergent literacy skills modulated by maternal educational attainment?

\subsection{Significance of the Study}

This study is significant for at least three fundamental reasons. First, Early Childhood Education in many developing countries, especially in Africa, is still at the rudimentary level, compared to primary education dating back to the Christian missionary era in the $17^{\text {th }}$ century. Hence, there are too many nebulous areas in preschool education that need further development. Therefore, the findings of this paper would constitute an invaluable source of literature to stakeholders. Secondly, since preschool education generally is still at the nurturing level in many developing nations), there are virtually few Colleges/Faculties/Schools of Education focusing specifically on Early Childhood Teacher Education and Training. The findings of this paper would be of benefit to such untrained teachers to understand the strong connectivity between the psychological precursors of home background and emergent literacy at the preschool. Third, there is low adult literacy in many developing countries, putting many children from poor and illiterate background at risk in literacy acquisition. The outcome of this study would inform teachers to pay extra attention to children from such background.

\section{Theoretical Framework/ Literature Review}

\subsection{Home Environment and Emergent Literacy Skills}

The development of literacy skills is a complex psychological process. It involves varied variables and experiences that overlap intricately with each other. The development begins at birth. Infants and babies hear and interpret meaning from the spoken word from significant others and siblings. This means the environment of the child as well as the parental literacy are critical to the child's literacy development long before formal schooling begins. Other consistent predicting factors for children's academic success include socio-economic factors. The last two decades have witnessed an explosion in research on early learning as both educators and researchers continue to search for answers to enhance literacy. Many are convinced that when pre-schooling literacy is incorporated into this search, it would enhance the over-all literacy and language development of children even before formal schooling. It is in this context that Richard Anderson, in his 1985 National Commission on reading, stated among others: "The single most significant factor influencing a child's early educational success is an introduction to books and being read to at home prior to beginning school" (Arnold \& Colburn, 2006, p. 31).

\subsection{Home Literacy Practices, Socioeconomic Status and Emergent Literacy Skills}

The convergence between children's achievement and home literacy practices at the level of preschool has received much attention. For example, measuring the following four literacy practices and their impact on children's linguistic development : a) maternal strategies to read books to children; b) frequency of mother-child shared book reading; c) children's enjoyment of reading and d) maternal disposition to literacy activities, the findings of Roberts, Jurgens and Burchinal (2005) suggested a positive connection between ages three and five. 
Additionally, the findings indicated a correlation between maternal sensitivity to children's receptivity to vocabulary acquisition, along the following variables: a) warmth; b) sensitivity; c) responsiveness; c) encouragement of initiative; d) stimulation value, and e) elaborateness. In a similar study, with a slant on home background socioeconomic status and children's achievement in early education, the findings of Ntim (2014), Ntim and Mavis (2014) also suggested children from urban Ghana with endowed socioeconomic status, were many times more likely to have more enhanced emergent literacy skills than children from indigent background. Parents from higher socioeconomic status with higher education, psychologically had tendency to explain things to their children in the homes using many elaborated codes. Less educated parents from the rural Ghana, most often used restricted codes. Therefore, the level of maternal sensitivity and responsiveness, stimulation as well as the extent of elaboration, etc., varied, and this constituted strong determining factors in shaping children's emergent literacy skills prior to formal schooling. Thus, one significant finding from these studies is that the home environment was the leading predictor for children's emergent literacy skills. Home parameters such as the primary caregiver, especially, the mother's emotional verbal and linguistic responsiveness, readiness to accept the child's behaviour, and above all, the maternal engagement with the child have greater impact on the child's literacy skills.

\subsection{Roles of Emotion in Language and Literacy Learning}

Lawson (1988) examined the differential roles of emotion and its impact on linguistic and literacy learning and how language learning was an internal process. Lawson (1988) findings showed a connection between children's initial linguistic and discourse skills as greatly enhanced by parental reading habits. For Lawson (1988), emotion conveyed by way of prosodic cues, pitch contour tempo as well as rhythm and loudness helped children to understand spoken language and the emotions of the one speaking. It is believed that infants have a natural tendency to prefer speech having prosodic cues such as sing-song. At the level of neurophysiology, findings showed that interactions having prosodic cues tended to build solid foundation for linguistic development and comprehension (Plant, Holland, \& Schmithorst, 2006). There is therefore strong emotional ties between child and care giver or mother. This emotional ties also precipitate in the child embedded directed speech, facilitating language and comprehension to develop faster.

\subsection{Theories on Children's Emergence Literacy skills: Traditional Model of Literacy Learning (Erickson, 1999) Traditional Model of Literacy Learning (Erickson, 1999)}

According to Erickson (1999), the traditional model of literacy learning is based on the subsequent four underlying assumptions: a) literacy is learned in a predetermined manner; $b$ ) sequential manner that is linear; c) additive and d) unitary. What is implied is that learning of literacy skills is acquired one after the other, and not in a concurrently and interrelated manner. Additionally, literacy skills are acquired only within the context of formal schooling, when certain background prerequisite's skills are acquired, based on which literacy learning can progress. This traditional view based on the behaviorists approach to learning which is essentially molecular in approach perceives the development of literacy skills first from listening skills, after which emerges speaking, and after speaking then comes readiness skills for reading and writing. 
2.5 Current/ Emergent View of Literacy Skills (Sulzby, E., \& Teale, W. 1991).

The above molecular approach to the learning of literacy skills has been rebutted in recent times. Acquisition of literacy skills is now perceived as a process beginning even before birth. This means that the reading and writing behaviours that precede formal schooling from the home background gradually develop into conventional literacy. For Sulzby and Teale (1991), emergent literacy skills are rather acquired in a more constructive, interactive, recursive manner. They emerge from children's oral language development and their initial and unconventional efforts at reading, which are usually based on pictures and unconventional attempts at drawing and scribbling. Therefore, they are not linear, sequential and predetermined. They emerge first from listening to oral language. The following six important implications could be drawn from this perspective: a) reading, writing, speaking and listening develop concurrently and interrelatedly, rather than linearly and sequentially; b) this process of learning to read and write starts at birth and it is a continuum; c) these literacy skills are socially learnt through the medium of active engagement with the world of the infants, especially through significant others such as parents and the home environment; d) acquisition of emergent literacy behvaiour are based on certain variables such as technology, text, task and environment. It is in this sense that they are perceived as fleeting behaviours; e) print are integrally related to literacy as the forms; f) other resources such as materials, media, technologies are critically essential to demonstrating impact on emergent literacy (Sulzby, \& Teale, 1991).

From the above emergent literacy view, not only does the learning of literacy develop concurrently and interrelatedly it is also critically fostered by certain kinds of environmental conditions and experiences that enhance significant interaction with oral as well as written language through social agency. This social agency could be an adult who on consistent occasions reads aloud to the child or narrates story by drawing (Sulzby \& Teale, 1991; Hiebert \& Papierz, 1989). These early experiences constitute the foundation for literacy acquisition before formal schooling (Mason \& Allen, 1986; McGee \& Lomax, 1990).

\subsection{New Literacy Studies and Social Turn Theory of James Paul Gee (1998)}

Psychological studies since the first half and the middle part of the last century were dominated by the behaviourist and cognitive approaches to the study of human learning. Consequently within and across many disciplines, especially in the Social Sciences, the last several decades have witnessed a paradigmatic shift from the behaviorists and cognitivists approaches which focused on individual behvaiour as well as individual minds respectively. The contemporary approach in the Social Sciences is towards a focused approach of social and cultural intervention to human learning. Typical of this contemporary model was the new literacy studies (Barton, 1994; Gee, 1996; Street, 1984).

The fundamental notion of the New Literacy Studies (NLS) is that reading, writing and making inference or meaning of something are situated within a specific context and specific social practices and discourse rather than in an individual behaviour or an individual mind (Gee, 1996). This view is tied up with specific socio-political contexts. For example, words derive their meaning within a given context. Words and contexts are like two mirrors facing and reflecting each other concurrently. Therefore, literacy skills such as reading, writing, knowledge, work, meaning as well as value and how they emerge are both inextricably 
connected with and embedded within social milieu. Gee (1998), made the submission that it was from a given context that a word or deed took its meaning and which at the same time helped to create and give that meaning. Therefore, outside of a given context, a meaning had no value. To illustrate this point, Gee (1998) offered the example of utterances such as 'sweet nothings'. This phrase has meaning only within the context of a romantic relationship and where the context of such relationships exists.

Furthermore, Gee (1998) argued that contexts and situations were created by actively, sustained, negotiated, resisted and even transformed by subjects. Language was not different in this respect. It was created, sustained and transformed enactively by subjects. Gee (1998) underlined that it was the social agent who created the context and the situation by uttering (writing) the words consciously and unconsciously with personal, social, cultural and political goals. Purposes were usually left out in the discourse. He gave as example the many postmodernists who referred to people as 'subjects', but not in the sense of these subjects authoring their words. Rather they spoke of their words authoring them and for Gee (1998) the two were not the same (see, e.g., Foucault 1972: pp. 95-96).

Applying this theory to the learning of emergent literacy skills, Gee (1998) claimed that similarly through the medium of words, deeds, etc., social agents (subjects) managed to get children to recognize peoples, things, symbols and ways of speaking, listening, writing, reading, feeling, believing, thinking, etc., as meaningful and valuable. It was in this context that things and symbols also become actors, influencing our thinking, and work on us, as we work on them as elaborated in Latour's actor-network theory (Latour, 1987; Latour, 1991). Wertsch's (1985) and Wertsch's (1991) ideas of Vygotsky made similar conclusion.

The above literature review could be summarised as: a) emergent literacy skills develops as a process, beginning even before birth and precedes formal schooling; b) since it precedes schooling, there is a connection between the developments of these skills and the home environment, especially home literacy practices and the emotional sensitivity of the caregiver or mother; and c) single most determining factor influencing children's emergent literacy skills is introduction to books, and being read to, which are both mediated through the agency of a social actor in a given sociocultural context. Based on these, this paper tested how predictive is the hypothesis of the Social Turn Theory of Gee (1998), Latour's actor-network theory (1987), Wertsch's $(1985 ; 1991)$ of how social agents (reading proficiency of the mother ) modulate children's emergent literacy skills.

\section{Methodology}

\subsection{Sample}

A random stratified purposive sampling of two hundred and fifty two (252) respondents, comprising one hundred and twenty mothers (120), one hundred and twenty (120) kindergarten children, and twelve (12) kindergarten teachers took part in this survey from three (3) communities in the Ashanti and the Ahafo regions of Ghana. Two of the communities were from the Kumasi Metropolis: Amakom and Asokwa. One community Bechem was also selected from the Ahafo region. Mothers were between the age range of 22 and 40 years with average age of 32.65. One hundred and eight (108) constituting $90 \%$ of these mothers were married, staying with partners and $10 \%$ (12) reported being single 
mothers'. In terms of academic attainments, forty eight (48) of these mothers (40\%) were university graduates, while 10\% (12) completed Senior High School, another 10\% (12) were trained teachers with Diploma in Basic Education. Out of the remaining forty eight (48) mothers, thirty (30) finished the Junior High School and eighteen, completed primary six.

Regarding socioeconomic status of these mothers, those staying with partners showed better characteristics compared with single mothers. On the average, mothers with higher educational attainment were twice better off financially whether single or married, compared with the less educated. The former had combined mean of US\$800 per annum, while the latter had an average of US\$200 about four times less than the highly educated.

The children (whose parents participated in this survey) and whose emergent literacy skills were matched against the reading habits of these mothers were also one hundred and twenty (120) across the three communities. Forty children were selected from each of the three communities. They were within the age range of three (3)-five (5) years. All of them were Ghanaians with an average age of 3 years 4 months. All had average length of one and a half years of being enrolled in Early Childhood Education. None was reported to have any disability. The twelve teachers selected from the three kindergarten across the regions, six (6) of them from the Kumasi Metropolis had the Diploma in Basic Education, two possessed the Bachelor of Education (Basic Education). The remaining four teachers from the other schools did not possess any professional qualification. In terms of age, they were between 18 and 25 years of age, with an average age of 22.85. All were females.

\subsection{Measures}

Table 1 gives a summary of emergent literacy skills at age four in Early Childhood Education during children's first measurement time points as well background information on their mothers. Emergent Literacy Skills measured at this age included the following: a) non-word repetition; b) receptive grammar; c) vocabulary; d) syllable deletion; e) rapid automatized naming and e) visual-spatial relationships. Early family factors measured with specific reference to maternal reading proficiency included: a) mother's level of education; b) mother's income; c) mother's number of children; d) number of adults books available to mother ; e) number of children's books available to mother ; f) mother's reading habits per day and per week; g) mother's reading habit per hour and per day; g) letter identification teaching age by mother; $h$ ) reading teaching age by mother.

\subsubsection{Non-word Repetition}

This measure was taken at the age of 3. Children were asked to repeat words that made no sense from syllables of 1 through 4 Non-word repetition was measured. Responses were scored as 0,1 , or 2 . This was used as an index for phonological working memory gat age 3 . (Lei et al., 2011; Nation \& Hulme, 2011).

\subsubsection{Receptive Grammar}

This was measured when children were at the age of 3 . Children were presented with sentence or phrase orally (e.g. eating kenkey) and were required to pick a picture that connected the description given by the experimenter (e.g. drinking water, eating kenkey, drinking milk, eating. This test was an adaption of Bishop's (1979). 


\subsubsection{Vocabulary}

This test was assessed when children were at age 4. Again experimenter orally presented 34 words that represented either ideas or objects through incremental conceptual difficulty. They were required to give an explanation of the meaning of each word. The full mark was 2 . To have a valid inter-rater reliability, two experimenters were asked to score children's answers. The Pilot test indicated a high inter-rater reliability between the two experimenters $(r>0.9)$. This vocabulary task was taken as a proper indicator for vocabulary knowledge (McBride-Chang et al., 2005; Pan et al., 2011; Song et al., 2015).

\subsubsection{Morphological Construction}

This task was performed at age 4. Children were tasked to combine separate morphemes they were aware of into new compound word such as a board with black colour was called 'blackboard, if the colour of the board was white, how would it be called?

\subsubsection{Early Family Factors}

The level of education of parents as well as their income were also gathered from the mothers who participated in this study beginning from the time these children were born. Questions regarding home literacy environment were asked when children were on the average at the age of 3years. This was measured using a six-point Likert scale:1) below primary $3 ; 2$ ) primary 4-6; 3) Junior High school; 4) Senior High School; 5) Undergraduate University; 6) Graduate School. The monthly income of parents was also measured with a six-point Likert's scale measured on the following points: 1) income below 1000 Ghana Cedis; 2) 1000 to 2,500 Ghana cedis; 3)2,500-5,000 Ghana Cedis; 4) 5000 to 10,000 Ghana cedis and 6) higher than 45,000 Ghana cedis.

\subsubsection{Number of Books at Home; Parents Reading Habits and Parent-Child Reading Tuition}

The number of books available in the home environment both adult as well as books for children were measured along the following Likert's scale: 1) 0-5; 2) 6-10;3) 11-25; 4) 4-26; 5) 51-100 and 6) more than 100. On parents reading habits, parents were asked the following two questions: a) how many times do they read books or newsletters. Second question was on how long they read each time. The question was measured on a five-point Likert's scale: 1) 0 day; 2) 1-2 days; 3) 3-4 days; 4) 5-6 days and 5) 7 days. The second question on duration of reading was measured as follows: 1) 0-10 minutes; 2) 11-30 minutes; 3)31-60 minutes; 4) 12 hours; 5) 2-4 hours; 6) more than 4 hours. On parent-child reading tuition, parents were asked to explain at what time they start giving reading tuition to their children specifically when they teach their children character identification and English reading respectively. Measures were taken along the following scales: 1) no plan; 2) after 4 years; 3) 3-4 years; 4) 2-3 year; 5) 1-2 years and 6) 0-1 year old.

\subsection{Statistical Analysis}

An exploratory factor analysis was conducted to reduce variables in children's early family characteristics to find out the underlying sources of variance. The consequent factors, and components were calculated as means of the variables having the highest loadings. Since the objective of this study was to measure how predictive the match between children's emergent literacy skills with maternal reading proficiency at Primary 5, linear regression analysis was used. To tease out the differential impact of early emergent literacy skills and family/home 
environmental factors to later literacy performance, univariate linear regression was used with the four literacy measures at Primary 5 as dependent variable with the early emergent literacy skills and family factors as independent factors.

To avoid the influence of extraneous variables on reliability and validity of measurement, such as the connection between age, sex as well as non-verbal IQ vis-à-vis subsequent literacy acquisition, all analyses were adjusted a priori for the three variables of age, sex and nonverbal IQ at the age of 4 . Additionally, family factor likely to show significant connection $(\mathrm{p}<0.05)$ with measures of literacy were simultaneously entered into multiple linear regression models and later added early linguistic skills. Again to crosscheck the possibility of the risk of multicollinearity, attention was paid to the tolerance and the VIF values of the early language skills in the analysis of regression. Path analyses were conducted in respect of the linguistic skills as mediating variables to clarify connections between family factor and literacy acquisition. Above all, to test the extent of effect of early linguistics skills on later literacy skills a secondary path analysis was performed to check this. To measure the significance of the mediation effect, bias booth strapping producing confidence interval from percentiles was used and $95 \%$ confidence interval was used in this study.

Table 1. Descriptive statistics for 4-year old literacy skills and early linguistic and family factors

\begin{tabular}{|c|c|c|c|c|c|}
\hline Measures & Range & Mean (S.D.) & Skewness & Kurtosis & Reliability \\
\hline \multicolumn{6}{|l|}{ 4-Year old Literacy skills } \\
\hline $\begin{array}{l}\text { Letter recognition (items } \\
\text { correct/140) }\end{array}$ & $64-140$ & $120.1(12.9)$ & -1.4 & 2.4 & 0.97 \\
\hline $\begin{array}{l}\text { Reading fluency } \\
\text { (characters } / 3 \mathrm{~min})\end{array}$ & $260-2477$ & $1051.2(410.1)$ & 0.6 & 0.6 & 0.96 \\
\hline $\begin{array}{l}\text { Character spelling (items } \\
\text { correct/35) }\end{array}$ & $6-35$ & $22.4(6.0)$ & -0.2 & -0.5 & 0.90 \\
\hline $\begin{array}{l}\text { Reading comprehension } \\
\text { (items correct/40) }\end{array}$ & $0-40$ & $31.2(6.6)$ & -1.0 & 1.4 & 0.85 \\
\hline \multicolumn{6}{|l|}{ Early linguistic skills } \\
\hline $\begin{array}{l}\text { Non- word repetition } \\
\text { (score/24) }\end{array}$ & $1-20$ & $10.9(4.9)$ & 0.0 & -0.6 & 0.82 \\
\hline $\begin{array}{l}\text { Receptive grammar (items } \\
\text { correct/86) }\end{array}$ & $0-82$ & $58.4(12.5)$ & -1.2 & 3.0 & 0.91 \\
\hline $\begin{array}{l}\text { Syllable deletion (items } \\
\text { correct/15) }\end{array}$ & $0-15$ & $8.0(4.9)$ & -0.5 & -1.2 & 0.95 \\
\hline $\begin{array}{l}\text { Morphological } \\
\text { construction } \\
\text { correct/15) }\end{array}$ & $0-15$ & $9.8(3.2)$ & -1.1 & 1.5 & 0.81 \\
\hline $\begin{array}{l}\text { Rapid automatized naming } \\
\text { (items/s) }\end{array}$ & $0.4-2.4$ & $1.3(0.4)$ & 0.5 & 0.2 & 0.78 \\
\hline Vocabulary (score/64) & $0-18$ & $6.2(3.7)$ & 0.5 & -0.3 & 0.56 \\
\hline Visual-spatial relationships & $1-16$ & $10.8(3.7)$ & -1.0 & 0.5 & 0.93 \\
\hline
\end{tabular}


(items correct/16)

Early family factors

Maternal education

1-7

4.7(1.0)

0.1

0.2

Paternal education

$3-7$

$4.9(1.1)$

0.3

$-0.7$

Maternal income

4.5(1.4)

$-0.5$

$-0.9$

Paternal income

$4.9(1.0)$

$-1.5$

3.4

Number of adults' books

4.9(1.6)

$-0.8$

0.0

Number of children's 1-6

$4.8(1.2)$

$-0.3$

$-0.2$

books

Parents' reading habit 1-5

$4.9(1.1)$

$-2.0$

2.5

(days/week)

Parents' reading habit 1-6

$3.1(1.0)$

0.3

0.1

(hours/day)

Character teaching age $\quad 1-6$

4.2(1.0)

$-0.6$

0.6

Reading teaching age

$1-6$

4.7(1.2)

$-1.0$

1.3

Table 2. Loading coefficients on all family variables in the factor analysis

\begin{tabular}{llll}
\hline \multirow{2}{*}{ Measures } & \multicolumn{2}{l}{ Component } & \\
\cline { 2 - 4 } & 1. Literacy environment & 2. SES & 3.Reading tuition \\
\hline Number of adults' books & $\mathbf{0 . 7 0 5}$ & -0.362 & 0.313 \\
Number of children's books & $\mathbf{0 . 6 7 8}$ & -0.158 & 0.322 \\
Parents' reading habit in days & $\mathbf{0 . 6 6 8}$ & -0.063 & 0.154 \\
Parents' reading habit in hours & $\mathbf{0 . 6 6 2}$ & 0.007 & 0.186 \\
Mothers' income & 0.147 & $\mathbf{- 0 . 7 9 4}$ & -0.023 \\
Fathers' income & -0.033 & $\mathbf{- 0 . 7 4 1}$ & 0.228 \\
Mothers' education & 0.599 & $\mathbf{- 0 . 6 5 6}$ & 0.056 \\
Fathers' education & 0.561 & $\mathbf{- 0 . 6 3 6}$ & 0.066 \\
Character teaching age & 0.202 & -0.046 & $\mathbf{0 . 8 3 3}$ \\
Reading teaching age & 0.357 & -0.142 & $\mathbf{0 . 7 7 8}$ \\
\hline
\end{tabular}

Table 3. Correlations among family factors, early predictors and literacy skills at age 11

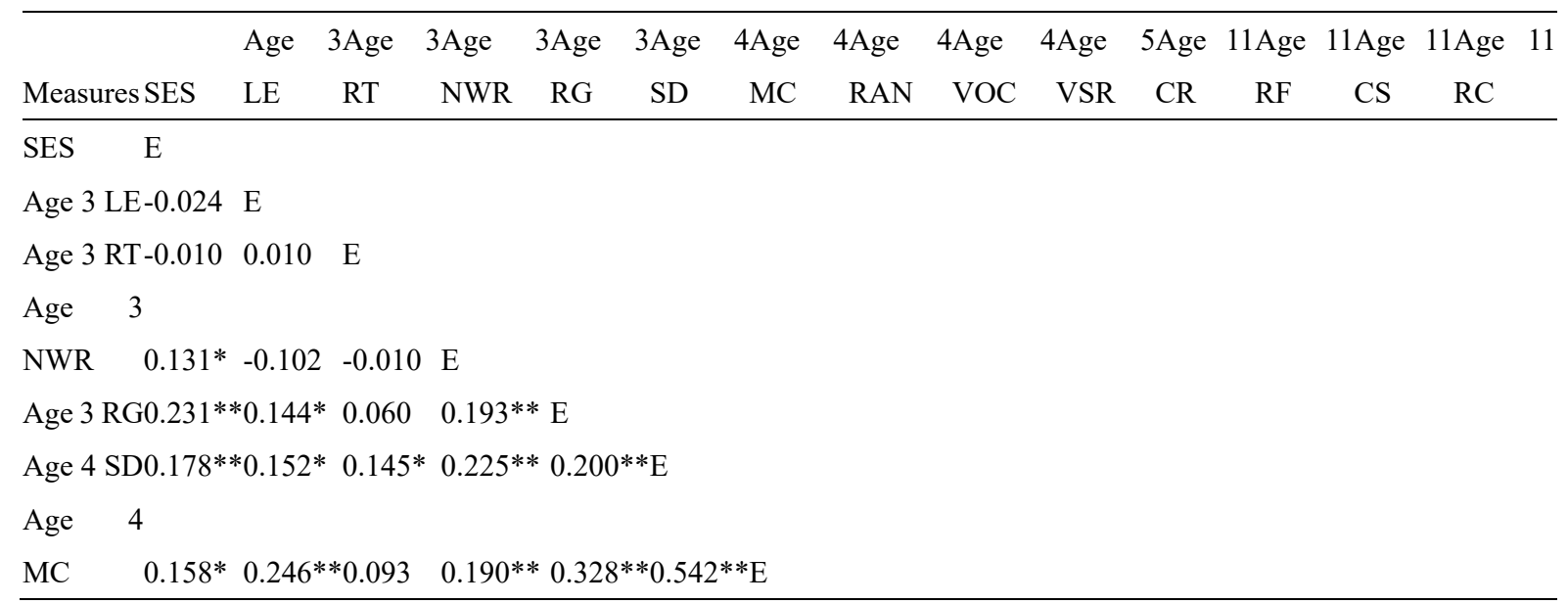




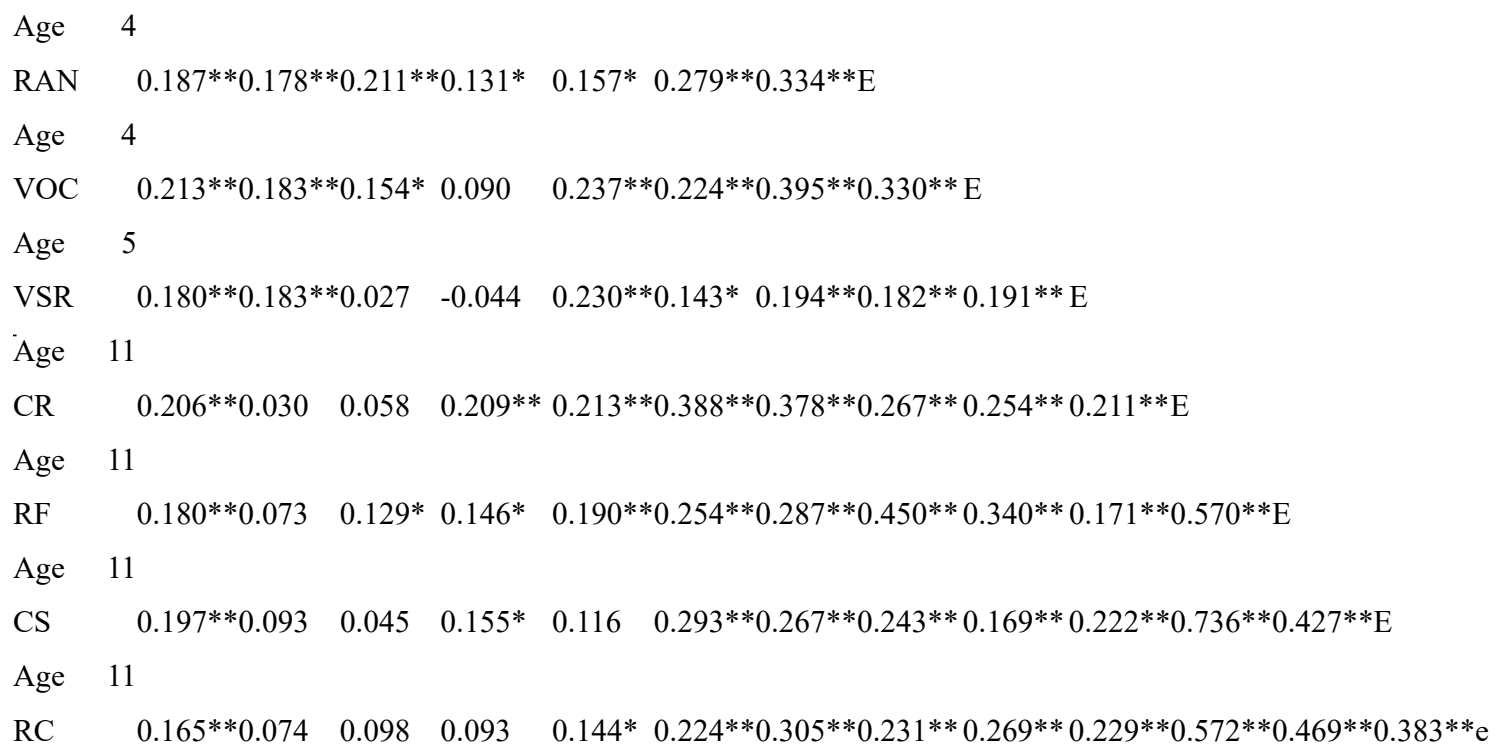

Table 4. Univariate regression analysis of 5th grade literacy skills using early family factors and early linguistic skills as predictors

\begin{tabular}{|c|c|c|c|c|c|c|c|c|}
\hline \multirow[t]{2}{*}{ Measures } & \multicolumn{2}{|c|}{$\begin{array}{l}\text { Character } \\
\text { recognition }\end{array}$} & \multicolumn{2}{|l|}{$\begin{array}{l}\text { Reading } \\
\text { fluency }\end{array}$} & \multicolumn{2}{|c|}{ Character spelling } & \multicolumn{2}{|c|}{ Reading comprehension } \\
\hline & $\mathrm{DR}^{2}$ & Beta & $\mathrm{DR}^{2}$ & Beta & $\mathrm{DR}^{2}$ & Beta & $\mathrm{DR}^{2}$ & Beta \\
\hline \multicolumn{9}{|l|}{ Control variables } \\
\hline Sex & 0.013 & 0.101 & $0.049 * *$ & $0.212^{* *}$ & 0.010 & 0.084 & $0.024 *$ & $0.144 *$ \\
\hline Age & 0.013 & 0.082 & 0.002 & 0.013 & $0.021 *$ & 0.112 & 0.002 & 0.021 \\
\hline Age 4 non-verbal IQ & 0.013 & 0.118 & $0.041 * *$ & $0.211 * *$ & 0.013 & 0.116 & $0.061 * *$ & $0.256^{* *}$ \\
\hline \multicolumn{9}{|l|}{ Early family factors } \\
\hline SES & $0.047 * *$ & $0.224 * *$ & $0.044 * *$ & $0.216^{* *}$ & $0.050 * *$ & $0.232 * *$ & $0.032 * *$ & $0.186^{* *}$ \\
\hline Age 3 literacy environment & 0.000 & 0.020 & 0.006 & 0.076 & 0.009 & 0.094 & 0.004 & 0.064 \\
\hline Age 3 reading tuition & 0.011 & 0.105 & $0.031 * *$ & $0.176^{* *}$ & 0.008 & 0.092 & $0.021^{*}$ & $0.145^{*}$ \\
\hline \multicolumn{9}{|l|}{ Early linguistic skills } \\
\hline Age 3 non-word repetition & $0.042 * *$ & $0.216^{* *}$ & $0.017^{*}$ & $0.149 *$ & $0.023 *$ & $0.162 *$ & 0.008 & 0.095 \\
\hline Age 3 receptive grammar & $0.044 * *$ & $0.223 * *$ & $0.034 * *$ & $0.194 * *$ & 0.012 & 0.120 & $0.020^{*}$ & $0.146^{*}$ \\
\hline Age 4 syllable deletion & $0.145^{* *}$ & $0.404 * *$ & $0.058 * *$ & $0.260 * *$ & $0.084 * *$ & $0.305 * *$ & $0.046^{* *}$ & $0.228 * *$ \\
\hline \multicolumn{9}{|l|}{ Age 4 morphological } \\
\hline construction & $0.137 * *$ & $0.396^{* *}$ & $0.076^{* *}$ & $0.292 * *$ & $0.068 * *$ & $0.282 * *$ & $0.086^{* *}$ & $0.313 * *$ \\
\hline Age 4 rapid object naming & $0.066^{* *}$ & $0.279 * *$ & $0.184 * *$ & $0.455^{* *}$ & $0.055 * *$ & $0.252 * *$ & $0.048^{* *}$ & $0.235^{* *}$ \\
\hline Age 4 vocabulary & $0.063 * *$ & $0.265^{* *}$ & $0.104 * *$ & $0.344 * *$ & $0.026^{* *}$ & $0.175^{* *}$ & $0.066^{* *}$ & $0.274 * *$ \\
\hline \multicolumn{9}{|l|}{ Age $\quad 5 \quad$ visual-spatial } \\
\hline relationships & $0.043 * *$ & $0.218 * *$ & $0.027 * *$ & $0.173 * *$ & $0.047 * *$ & $0.230 * *$ & $0.048 * *$ & $0.232 * *$ \\
\hline
\end{tabular}

Note: ${ }^{*} p<0.05 . * * p<0.01$. 
Table 5. Simultaneous multiple regression analysis of 5th grade literacy skills making use of early family factors and early linguistic skills as predicting factors

\begin{tabular}{|c|c|c|c|c|c|c|c|c|c|}
\hline \multirow[t]{2}{*}{ Measures } & \multicolumn{3}{|c|}{ Character recognition } & \multicolumn{2}{|l|}{ Reading fluency } & \multicolumn{2}{|c|}{ Character spelling } & \multicolumn{2}{|c|}{$\begin{array}{l}\text { Reading } \\
\text { comprehension }\end{array}$} \\
\hline & & $\mathrm{DR}^{2}$ & Beta & $\mathrm{DR}^{2}$ & Beta & $\mathrm{DR}^{2}$ & Beta & $\mathrm{DR}^{2}$ & Beta \\
\hline 1. Control variables & $0.038^{*}$ & & & $0.093 * *$ & & & & $0.087 * *$ & \\
\hline Sex & & & 0.086 & & $0.173 * *$ & & 0.076 & & $0.131 *$ \\
\hline Age & & & 0.022 & & 0.084 & & 0.047 & & 0.077 \\
\hline Non-verbal IQ & & & 0.108 & & 0.012 & & 0.068 & & 0.076 \\
\hline 2. Early family & & & & & & & & & \\
\hline factors & $0.048 * *$ & & & $0.0643 * *$ & & $* *$ & & $0.047 * *$ & \\
\hline SES & & & 0.059 & & 0.039 & & 0.117 & & 0.052 \\
\hline Age 3 literacy & & & & & & & & & \\
\hline environment & & & $\mathrm{E}$ & & $\mathrm{E}$ & & $\mathrm{E}$ & & $\mathrm{e}$ \\
\hline Age 3 reading tuition & & & $\mathrm{E}$ & & 0.046 & & $\mathrm{E}$ & & 0.058 \\
\hline 3. Early linguistic & & & & & & & & & \\
\hline skills & $0.186^{* *}$ & & & $0.180 * *$ & & $* *$ & & $0.100 * *$ & \\
\hline Age 3 non-worc & & & & & & & & & \\
\hline repetition & & & 0.116 & & 0.063 & & 0.099 & & 0.041 \\
\hline Age 3 receptive & & & & & & & & & \\
\hline grammar & & & 0.035 & & 0.042 & & 0.048 & & 0.017 \\
\hline Age $\quad 4 \quad$ syllable & & & & & & & & & \\
\hline deletion & & & $0.223 * *$ & & 0.068 & & $0.160^{*}$ & & 0.042 \\
\hline Age 4 morphologica & & & & & & & & & \\
\hline construction & & & 0.147 & & 0.030 & & 0.093 & & $0.166^{*}$ \\
\hline Age 4 rapid objec & & & & & & & & & \\
\hline naming & & & 0.088 & & $0.330 * *$ & & 0.112 & & 0.071 \\
\hline Age 4 vocabulary & & & 0.073 & & $0.166^{*}$ & & 0.008 & & 0.122 \\
\hline Age 5 visual-spatia & & & & & & & & & \\
\hline relationships & & $\mathrm{R}^{2}$ & $1 / 40.113$ & & 0.047 & $\mathrm{R}^{2}$ & $1 / 40.158^{*}$ & & $0.147^{*}$ \\
\hline & & 0.272 & & $\mathrm{R}^{2} 1 / 40.336$ & & 0.201 & & $\mathrm{R}^{2} 1 / 40.234$ & \\
\hline
\end{tabular}

Note: yp $1 / 40.05 .{ }^{*} \mathrm{p}<0.05 .{ }^{* *} \mathrm{p}<0.01$.

\section{Discussion}

This study examined whether or not there is predictive power between maternal reading proficiency at the preschool period and early cognitive literacy skills acquisition at primary five. Using an empirical approach, the underlying thesis of this study was that emergent literacy skills develops as a process, beginning even before birth. Therefore, emergent literacy skills development precedes formal schooling. This implies that there is an intrinsic connection between the developments of emergent literacy skills and the home environment, 
especially home literacy practices as well as the mother's emotional sensitivity. Rebutting the traditional model of Literacy Learning of Erickson (1999) that learning of literacy skills is learnt one after the other, and not in a concurrently and interrelated manner, this study tested empirically the theoretical model of New Literacy Studies that reading, writing and making inference or meaning of something are always situated within a specific context and specific social practices and discourse and not in an individual behaviour or an individual mind. Therefore, literacy skills such as reading, writing, knowledge, work, meaning as well as value and how they emerge are both inextricably connected with and embedded within social milieu, especially social agents such as the mother (Barton, 1994; Gee, 1996; Latour, 1987, Street, 1984; Wertsch's 1985; 1991)

The findings suggest that variance in literacy achievement at primary five were largely mediated by early precursors of family home background experiences: availability to books, reading proficiency of the mother, how many times a mother would read to children, etc. One of the key findings was the extent of correlation between family factors and literacy skills. Literacy skills were almost entirely mediated by early linguistic skills acquisition. Specifically, the analysis of variance indicated that for example both phonological and morphological awareness during preschool at age 4, mediated the causal connection with respect to early family socioeconomic status and children's ability at age 11 on character recognition. Another major finding was that children's vocabulary acquisition at age 4, mediated a connection between early family factors such as mother's socioeconomic status and mother-child reading tuition at home, and how fluent children could read at age 11 . Children from maternal backgrounds with higher level of educational qualification were more likely to have access to home reading tuition. Such children performed highly on reading fluency at primary five. As found in early longitudinal studies that explored the predicting factors of literacy ability especially in alphabetic orthographies such as Roth et al. (2002), this study found a relatively predictive power of prelinguistic skills as well as early family environmental backgrounds factors on 5th grade literacy skills. This underscores the significant impact of early literacy skills and the family environment with respect to later literacy achievement (Whitehurst \& Lonigan, 1998). Formal schooling has a tendency to quicken children's literacy skills. It was also evident from this study that vocabulary acquisition at age 4 was mediated principally through the link between early families' factors, especially the socioeconomic status but especially also parent-child reading tuition at a very early age which influenced reading fluency at age 11. Similarly, phonological awareness at age 4 as well as visual skills at age 5 showed an association between family socioeconomic and reading comprehension.

Another significant finding in this study is the importance of family background influence with respect to later literacy ability as indicated in the univariate regression analyses. What came out strongly were two variables: parental education and income. The more parents/family were endowed, the likelihood that the child could do better on literacy skills. Similarly, parental education especially that of the mother was the most significant factor as indicated in Table 2. This corroborates other findings on the correlation between socioeconomic status and language development in early literacy studies (Ntim, 2014; Ntim \& Mavis, 2014; Noble et al., 2007). This suggests the significant predictive factor of 
socioeconomic status as critical predictor of literacy achievement especially reading tuition in the home.

The above notwithstanding, it is important also to note that the correlation between two variables, namely, family factors and later academic literacy skills seems to get less strong in the context of early linguistic skills. Path analyses corroborated the association between early family factors and later literacy ability as mediated by early linguistic skills is consistent with findings of several studies that are suggestive of similar effects of emergent reading and language skills (Hood et al., 2008; Manolitsis et al., 2013; Rowe \& Goldin-Meadow, 2009; Zhang, Tardif et al., 2013). One significant contribution of this longitudinal study is the attempt to explore also some of the indirect effects of early factors from home background and how these have impact on a wide range of literacy skills from early childhood education through to primary five. Over-all, the results show how predictive the actions of the early family environment are, especially maternal reading proficiency, and that there is a strong correlation between children's family environment and the child's early linguistic skills.

What is critically significant from the above findings is not so much the correlation between early family environment and the children's early linguistics skills but rather the fact that the early linguistic and cognitive skills especially from the mother becomes the mechanism by which early family environment mediates influence on later literacy achievement. This reinforces the notion that even though, it is difficult to significantly improve early family environmental factors of some children, nevertheless, designing classroom intervention directly for disadvantaged children on their cognitive and linguistic skills is both feasible and possible to compensate for environmental disadvantage.

\section{Conclusion}

Literacy achievement especially reading skills at formal schooling is significantly mediated by early precursors of home environment, particularly maternal proficiency in reading. The more a child is read to in the homes before formal schooling, the higher the chances that such as a child would perform better in reading achievement at primary five. This is because emergent literacy skills, such as children's awareness of phonology and morphology from the homes are more likely to sharpen such children's ability on character recognition at age 11, than a child not so exposed. This places children from educated homes who have access to home reading tuition especially by the mother (because of the emotional bond between mothers and children) to perform better in reading. The findings of this study has underscored the age-old issue of educational access on one hand, and children from disadvantaged home on the other. Pedagogically, teachers have less control of home background factors which significantly influence children's school achievement, nevertheless, teachers could design specific instructional interventions to help bridge the gap between children from advantaged and disadvantaged backgrounds.

\section{References}

Anderson, R., \& Cheung, S. (2003). Time to read: Family resources and educational outcomes in Britain. Journal of Comparative Family Studies, 34(3), 413-433.

https://doi.org/10.3138/jcfs.34.3.413 
Arnold, R., \& Colburn, N. (2006). Really good research. School Library Journal, 52(11), 31. Barton, D. (1994). Literacy: An introduction to the ecology of Written Language. Oxford: Blackwell.

Bishop, D. V. (1979). Comprehension in developmental language disorders. Developmental Medicine \& Child Neurology, 21(2), 225e238. https://doi.org/10.1111/j.1469-8749.1979. tb01605.x

Bowman, B., Donovan, M., \& Burns, M. (2001). Eager to learn; Educating our preschoolers. Washington DC: Academy press

Boyer, E. (1991). Ready to learn: A mandate for nation. Princeton NJ: The Cambridge Foundation for advancement of Teaching.

Burgess, S. R., Hecht, S. A., \& Lonigan, C. J. (2002). Relations of the home literacy environment (HLE) to the development of reading-related abilities: A one-year longitudinal study. Reading Research Quarterly, 37(4), 408-426. https://doi.org/10.1598/RRQ.37.4.4

Bus, A. G., van Ijzerldoorn, M. H., Pellegrini, A. D. (1995). Joint book reading makes for success in learning to read: A meta-analysis on intergenerational trans-mission of literacy. Review of Educational Research, 65, 1-21. https://doi.org/10.3102/00346543065001001

Dickinson, D. K., \& Tabors, P. O. (2001). Beginning literacy with language: Young children learning at home and in school. Baltimore, MD: Paul H. Brookes Publishing Co.

Emergent literacy. In R. Barr, M. L. Kamil, P. B. Mosenthal, \& P. D. Pearson (Eds.), Handbook of reading research (Vol. 2, pp. 727-757). New York: Longman.

Entwisle, D. R., \& Alexander, K. L. (1998). Facilitating the transition to first grade: The nature of transition and research on factors affecting it. The Elementary School Journal, 98(4), 351-364. https://doi.org/10.1086/461901

Erickson. (1999). A problem-based approach to mathematics instruction. Mathematics Teacher, 92, 516-521. https://doi.org/10.5951/mt.92.6.0516

Foucault, M. (1972). The archaeology of knowledge. London: Tavistock.

Garrett, J. J. (2002). The elements of user experience: User-centered design for the Web.

Gee, J. P. (1996). Social linguistics and literacies: Ideology in discourses (2nd Ed.) London: Taylor \& Francis.

Gee, J. P. (1998). The new literacy studies: From "socially situated" to the work of the social, retrieved April, 22, 2019 from jamespaulgee.com/pdfs/The New Literacy Studies and the Social Turn.pdf

Hart, B., \& Risley, T. R. (1995). Meaningful differences in the everyday experiences of young American children. Baltimore: Brookes.

Hiebert, E. H., \& Papierz, J. M. (1990). The emergent literacy construct and kindergarten and readiness books of basal reading series. Early Childhood Research Quarterly, 5(3), 317-334. https://doi.org/10.1016/0885-2006(90)90024-u

Hood, M., Conlon, E., \& Andrews, G. (2008). Preschool home literacy practices and children's literacy development: A longitudinal analysis. Journal of Educational Psychology, 100(2), 252-271. https://doi.org/10.1037/0022-0663.100.2.252 
Klesius, J. P., \& Griffith, P. L. (1996). Interactive storybook reading for at-risk learners Reading Teacher, 49(7), 552-60.

Latour, B. (1987). Science in action. Cambridge, Mass.: Harvard University Press.

Latour, B. (1991). We have never been modern. Cambridge, Mass.: Harvard University Press.

Lawson, K. (2012). The real power of parental reading aloud: Exploring the affective and attentional dimensions. Australian Journal of Education 56(3), 257. https://doi.org/ 10.1177/000494411205600305

Lei, L., Pan, J., Liu, H., McBride-Chang, C., Li, H., \& Zhang, Y. (2011). Developmental trajectories of reading development and impairment from ages 3 to 8 years in Chinese children. Journal of Child Psychology and Psychiatry, 52(2), 212e220. https://doi.org/ 10.1111/j.1469-7610.2010.02311.x

Manolitsis, G., Georgiou, G. K., \& Tziraki, N. (2013). Examining the effects of home literacy and numeracy environment on early reading and math acquisition. Early Childhood Research Quarterly, 28(4), 692e703. https://doi.org/10.1016/j.ecresq.2013.05.004

Mason, J., \& Allen, J. B. (1986). A review of emergent literacy with implications for research and practice in reading. Review of Research in Education, 13, 3-47. https://doi.org/ $10.2307 / 1167218$

Mcbride-Chang, C., \& Ho, S. H. (2005). Predictors of beginning reading in Chinese and English: A 2-year longitudinal study of Chinese kindergartners. Scientific Studies of Reading, 9(2), 117-144. https://doi.org/10.1207/s1532799xssr0902_2

McGee, L. M. \& Lomax, R. G. (1990). On combining apples and oranges: A response to Stahl and Miller. Review of Educational Research, 60(1), 133-140. https://doi.org/10.3102/ 00346543060001133

Nation, K., \& Hulme, C. (2011). Learning to read changes children's phonological skills: Evidence from a latent variable longitudinal study of reading and nonword repetition. Developmental Science, 14(4), 649e659. https://doi.org/10.1111/j.1467-7687.2010.01008.x

Noble, K. G., McCandliss, B. D., \& Farah, M. J. (2007). Socioeconomic gradients predict individual differences in neurocognitive abilities. Developmental Science, 10(4), 464-480. https://doi.org/10.1111/j.1467-7687.2007.00600.x

Ntim, S. (2014). Early childhood exposure to literacy skills as better predictor of reading achievement: A longitudinal study from Ghana. Journal of Educational and Social Research, 4(6), 379-389. https://doi.org/10.5901/jesr.2014.v4n6p379

Ntim, S., \& Okyere, M (2014). Synergy between home environmental features, early language literacy and later reading achievement: Comparative study of urban, semi-urban and rural Ghanaian children International Journal of Humanities and Social Science, 8(1), 291-300.

Pan, J., McBride-Chang, C., Shu, H., Liu, H., Zhang, Y., \& Li, H. (2011). What is in the naming? A 5-year longitudinal study of early rapid naming and phonological sensitivity in relation to subsequent reading skills in both native Chinese and English as a second language. Journal of Educational Psychology, 103(4), 897. https://doi.org/10.1037/a0024344

Plante, E., Holland, S. K., \& Schmithorst, V. J. (2006). Prosodic processing by children: An fMRI study. Brain and Language, 97(3), 332-342. https://doi.org/10.1016/j.bandl.2005.12.004 


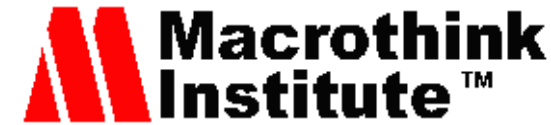

International Research in Education

ISSN 2327-5499

2021, Vol. 9, No. 1

Roberts, J., Jurgens, J., \& Burchinal, M. (2005). The role of home literacy practices in preschool children's language and emergent literacy skills. Journal of Speech, Language, and Hearing Research, 48(2), 345-359 https://doi.org/10.1044/1092-4388(2005/024)

Roth, F. P., Speece, D. L., \& Cooper, D. H. (2002). A longitudinal analysis of the connection between oral language and early reading. The Journal of Educational Research, 95(5), 259e272. https://doi.org/10.1080/00220670209596600

Rowe, M. L., \& Goldin-Meadow, S. (2009). Differences in early gesture explain SES disparities in child vocabulary size at school entry. Science, 323(5916), 951e953. https://doi.org/10.1126/science.1167025

Sénéchal, M., \& Young, L. (2008). The effect of family literacy interventions on children's acquisition of reading from kindergarten to Grade 3: A meta-analytic review. Review of Educational Research, 78(4), 880-907. https://doi.org/10.3102/0034654308320319

Song, S., Su, M., Kang, C., Liu, H., Zhang, Y., \& McBride-Chang, C. (2015). Tracing children's vocabulary development from preschool through the school-age years: An 8-year longitudinal study. Developmental Science, 18, 119e131. https://doi.org/10.1111/desc.12190

Storch, S. A., \& Whitehurst, G. J. (2001). The role of family and home in the literacy development of children from low-income backgrounds. In P. R. Britto, \& J. Brooks-Gunn (Eds.), New directions for child and adolescent development. The role of family literacy environments in promoting young children's emerging literacy skills (pp. 53-71). Jossey-Bass. https://doi.org/10.1002/cd.15

Street, B. (1984). Literacy in theory and practice. Cambridge: Cambridge University Press.

Strickland, D. S. (1990). Emergent Literacy: How young children learn to read and write. Educational Leadership, 47(6), 18-23.

Sulzby \& Teale (1991). Emergent literacy. In R. Barr, M. L. Kamil, P. B. Mosenthal, \& P. D. Pearson (Eds.), Handbook of reading research (Vol. 2, pp. 727-757). New York: Longman.

Swank, L., \& Catts, H. (1994). Phonological awareness and written word decoding. Language, Speech, and Hearing Services in Schools, 25, 9-14. https://doi.org/10.1044/01611461.2501.09

Teale, W. H., \& Sulzby, E. (1987). Literacy acquisition in early childhood: The roles of access and mediation in storybook reading. In D. A. Wagner (Ed.), The future of literacy in a changing world (pp. 111-130). New York: Pergamon Press.

Weigel D., Martin S., \& Benett, K. (2006). Mothers' literacy beliefs: Connections with the home literacy environment and pre-School children's literacy development Journal of Early Childhood Literacy, 6(2).

Wertsch, J. V. (1985). Vygotsky and the social formation of mind. Cambridge, Mass.: Harvard University Press.

Wertsch, J. V. (1991). Voices of the mind: A sociocultural approach to mediated action. Cambridge, Mass: Harvard University Press.

Whitehurst, G. J., \& Lonigan, C. J. (1998). Child development and emergent literacy. Child Development, 69(3), 848e872. https://doi.org/10.1111/j.1467-8624.1998.tb06247.x

Zhang, Y., Tardif, T., Shu, H., Li, H., Liu, H., \& McBride-Chang, C. (2013). Phonological 


\section{Macrothink}

International Research in Education

ISSN 2327-5499

2021, Vol. 9, No. 1

skills and vocabulary knowledge mediate socioeconomic status effects in predicting reading outcomes for Chinese children. Developmental Psychology, 49(4), 665. https://doi.org/10. $1037 / \mathrm{a} 0028612$

\section{Copyright Disclaimer}

Copyright reserved by the authors.

This article is an open-access article distributed under the terms and conditions of the Creative Commons Attribution license (http://creativecommons.org/licenses/by/4.0/). 